\title{
Effect of plant diversification on abundance of South American tomato pinworm and predators in two cropping systems
}

\author{
Maria A Medeiros ${ }^{1 ; 3}$; Edison R Sujiii²; Helena C Morais $^{3}$ \\ ${ }^{1}$ Embrapa Hortaliças, C. Postal 218, 70359-970 Brasília-DF; Embrapa Cenargen, Brasília-DF; ${ }^{3}$ Depto. de Ecologia, UnB, Brasília-DF; \\ medeiros@cnph.embrapa.br; sujii@cenargen.embrapa.br; morais@unb.br
}

\begin{abstract}
Several studies have demonstrated that the diversification of the agroecosystem may reduce insect pest infestation using the strategy of companion planting. We studied the effect of the presence of coriander and Gallant soldier as companion plants in the tomato crop under organic and conventional management on abundance of the tomato pests and predators. The experiment was carried out under field conditions, at Distrito Federal, Brazil, from July to October, 2004. The experimental design was of randomized blocks with three replicates in a $3 \times 2$ factorial arrangement [Three crop diversification levels: tomato in monoculture, tomato intercropped with coriander, and tomato intercropped with coriander and Gallant soldier; and two cropping systems: organic and conventional]. Each plot had 80 plants of the tomato and the pest-insects and predaceous arthropods were collected every week in five tomato plants/plot. Tuta absoluta (Meyr.) was the commonest pest species in both cropping systems. The tomato intercropped with coriander and Gallant soldier in organic cropping system had lower abundance and higher diversity of pests, and higher abundance and diversity of predaceous arthropods, mainly at 80 days after the tomato transplanting, coinciding with the population peak of $T$. absoluta (eggs and adults). The more abundant predators were spiders, lady beetles and ants. The spiders were abundant and uniformly distributed in both systems. The lady beetles appeared lately in the organic system, at the flowering season of the coriander. The ants were more abundant in the conventional systems.
\end{abstract}

Keywords: Lycopersicon esculentum, Coriandrum sativum, Galinsoga parviflora, Tuta absoluta, habitat manipulation, conservation biological control.

\section{RESUMO}

Efeito da diversificação de plantas na abundância da traçado-tomateiro e predadores em dois sistemas de cultivo

Vários estudos têm demonstrado que a diversificação do agroecossistema pode reduzir a infestação por insetos-praga pelo uso da estratégia do estabelecimento de plantas companheiras. Neste trabalho estudou-se o efeito da presença do coentro e botão-de-ouro como plantas companheiras na cultura do tomate sob manejo orgânico e convencional, na abundância das pragas do tomate e de predadores. O experimento foi conduzido em condições de campo, no Distrito Federal, de julho a outubro de 2004. O desenho experimental foi em blocos ao acaso, com três repetições e no arranjo fatorial $3 \mathrm{x}$ 2 [três níveis de diversificação cultural: tomate em monocultivo, tomate consorciado com coentro, e consórcio tomate com coentro e botão-de-ouro e dois sistemas de cultivo: orgânico e convencional]. Cada parcela experimental tinha 80 plantas de tomateiro, sendo os insetos-praga e artrópodes predadores semanalmente coletados em cinco plantas/parcela. Tuta absoluta (Meyr.) foi a espécie-praga mais comum em ambos os sistemas de cultivo. $\mathrm{O}$ tomate consorciado como coentro e botão-de-ouro, no sistema de cultivo orgânico, apresentou menor abundância e maior diversidade de pragas, e maior abundância e diversidade de artrópodes predadores, principalmente aos 80 dias após o transplantio do tomate, coincidindo com o pico populacional da T. absoluta (ovos e adultos). Os predadores mais abundantes foram aranhas, joaninhas e formigas. As aranhas foram abundantes e uniformemente distribuídas em ambos os sistemas. As joaninhas apareceram tardiamente no sistema orgânico, no período de florescimento do coentro. As formigas foram mais abundantes no sistema convencional.

Palavras-chave: Lycopersicon esculentum, Coriandrum sativum, Galinsoga parviflora, Tuta absoluta, manipulação do habitat, controle biológico conservativo.

(Recebido para publicação em 24 de novembro de 2008; aceito em 20 de agosto de 2009)

(Received in November 24, 2008; accepted in August 20, 2009)

$\mathrm{T}$ he tomato, Lycopersicon esculentum (Mill.) (Solanaceae) is susceptible to several pests, such as lepidopteran leafminers and borers, aphids, whiteflies and thrips (França et al., 2000; Haji et al., 2002). Among them, the South American tomato pinworm (SATP) Tuta absoluta (Meyrick) (Lepidoptera: Gelechiidae) is a serious limiting pest of tomato in conventional and organic cropping systems in Brazil (França et al., 2000; Grassi, 2005). Its distribution is restricted to countries which are producers of tomato in Latin America (França, 1993; França et al., 2000).

The SATP damages are caused by the caterpillars that destroy leaves, stems and fruits, besides facilitating the contamination by pathogens (França et al., 2000). In Central Brazil, this pest is present throughout the year due to favorable weather conditions, especially the temperature, and its population peaks occur from July to September, i.e., during dry and hot periods (Haji et al., 1988; Castelo Branco, 1992).

In conventional cropping system, the use of chemical insecticides is the primary method to control the SATP, although it is not always effective (Haji et al., 1995; Souza et al., 1992). However, these pesticides are not permitted in organic cropping system. 
Due to the economic importance of this crop, other methods to control this pest have been studied by several authors, such as genetic resistance of plants (Lourenção et al., 1984; Thomazini et al., 2001), use of entomopathogens (Giustolin et al. 2001a, 2001b) and botanical insecticides (Brunherotto \& Vendramim, 2001; Thomazini et al., 2001). The biological control with the parasitoid Trichogramma pretiosum Ridley (Hymenoptera: Trichogrammatidae) is successful against the SATP, but it is susceptible to insecticides applied against the whitefly Bemisia tabaci (Genn.) (Hemiptera: Aleyrodidae, and is reared by specialized laboratory to be applied through augmentative biological control (Haji et al., 2002).

However, another future perspective for pest control is the habitat manipulation by enhancing diversification of plant species in time and space in annual cropping habitats. This strategy is based on the companion planting, which can be described as the establishment of two or more plant species in close proximity so that some cultural benefit is derived, such as pest control (Kuepper \& Dodson, 2001). Habitat manipulation may occur at the within-crop, within-farm, or landscape levels. Various techniques to restore agricultural diversity in time and space include crop rotations, cover crops, vegetation handling, intercropping (or polycultures) and more complex cropping systems, such as ecological corridors and agroforestry systems (Altieri et al., 2003; Nicholls \& Altieri, 2006).

Several studies carried out in the USA, Europe and Australia have demonstrated the role of crop diversification in reducing insect pest infestation, and the mechanisms accounting for reduction, such as reduced pest colonization rate, reduced pest tenure time, oviposition interference, and increased mortality due to predators and/or parasitoids (Hooks \& Johnson, 2003; Ponti et al., 2007). These mechanisms underlie two hypotheses to explain lower pest infestations in diversified cropping systems: the resource concentration hypothesis and the natural enemy hypothesis (Root, 1973; Ponti et al., 2007).
Under the first assumption, a more diverse flora in the agroecosystem impairs the ability of insect pests to find and utilize their host plant by chemical repellence, camouflage, feeding inhibition by the presence of non-host plants and reduction of immigration that result in lower colonization and reproduction of pest (Root, 1973; Ponti et al., 2007). The second hypothesis presumes that more diverse cropping systems enhance abundance and diversity of natural enemies that reduces pest numbers (Andow, 1991, Ponti et al., 2007), and implied the implementation of habit manipulation of non-crop species (beneficial insectary plants) in the agroecosystem to provide vital resources for natural enemies of the crop pests, which is known as conservation biological control (Landis et al., 2000). The concept of encouraging beneficial insects with insectary (flowering) plants is based on the requirement for many adult predatory and parasitic insects to feed on nectar and/or pollen, including aphidophagous hover-flies, tachinid flies, ladybird beetles, lacewings and parasitic Hymenoptera (Smith, 1960; Colley \& Luna, 2000; Berndt \& Wratten, 2005). The larvae of these beneficial insects are the primary feeding stage on herbivorous arthropods.

Wild or cultivated flowering plants, including weeds, in or around the field, can increase the diversity of habitats and provide shelter, suitable microclimate and alternative food sources for natural enemies and can significantly increase the residency times and thus enhance the efficacy of predators and parasitoids (Emden, 1965; Altieri \& Whitcomb, 1979; Landis et al., 2000; Altieri et al., 2003; Berndt \& Wratten, 2005).

Research is still needed to identify which companion plants have the greatest potential for reducing pest infestation of the main crops. Species of Leguminosae, Apiaceae and Asteraceae have played the role as beneficial insectary plants (Altieri et al., 2003). According to Landis et al. (2000), the selection of plants for habitat manipulation should consider their suitability in the agricultural or horticultural regime in which they will be placed. However, as pointed out by Hooks \& Johnson
(2003), the indirect role that habitat manipulation plays in the population dynamics of inset pests and natural enemies still remains unclear. Previous studies conducted in Brazil indicated that SATP could respond, in a variable way, to the plant diversification of the environment.

In this context, the objective of this work was to study the effect of presence of the herb coriander (Coriadrum sativum L., Apiaceae) and the weed Gallant soldier (Galinsoga parviflora Cav., Asteraceae) as companion plants in tomato crop under organic and conventional managements on abundance of the tomato pests, mainly the SATP, and predators throughout the crop cycle.

\section{MATERIAL AND METHODS}

The experiment was conducted in two areas of the experimental field of Embrapa Hortaliças, located in Brasilia, Brazil (15 ${ }^{\circ} 56^{\prime}$ S, $48^{\circ} 08^{\prime} \mathrm{W}$ and $997.6 \mathrm{~m}$ a.s.l). The soil is characterized as Dark Red Latosoil (Oxisol).

The experimental design was a randomized block with three replicates in a $3 \times 2$ factorial arrangement: three crop diversification levels [tomato in monoculture, tomato intercropped with coriander, and tomato intercropped with coriander and Gallant soldier, a nonhost of tomato pest was used to provide floral resources to natural enemies; and two cropping systems: organic and conventional.

The organic cropping system was established in a special area intended for researching on organic vegetables production system, which has been under this management since 2001 . The organic and conventional areas are separated from each other at a distance of $100 \mathrm{~m}$. The proximity of the areas of organic and conventional production allows comparative experiments between organic and conventional systems in a paired way, a feature which is rarely found in this type of study.

The organic area has about $250 \mathrm{~m}$ of a riparian forest, and is policultivated (mainly onions, carrots, broccoli, cucumber and garlic), employs crop 
rotation with corn and uses corn and sorghum as green manure. It is surrounded by hedgerows of the Giant Mexican sunflower [Tithonia diversifolia (Hemsl.), Asteraceae] and uncultivated areas are maintained with spontaneous vegetation, which is dominated by the napier grass (Pennisetum purpureum Stapt., Poaceae) and brachiaria grass (Brachiaria decumbens Schum, Poaceae). In the hedges of the experiments, rows of corn (Zea mays L., Poaceae) and crotalaria (Crotalaria juncea L., Leguminosaceae) were established as a barrier.

The transplantation of the tomato seedlings (hybrid F1 "Duradoro") took place on July $2^{\text {nd }} 2004$ in both areas, and the crop remained in the field for 101 days (end of harvested period). Each plot was formed of 80 tomato plants spaced $0.50 \mathrm{~m}$ between plants and $0.80 \mathrm{~m}$ between rows in the inverted $\mathrm{V}$-shaped stake system with double rows totalizing $25.2 \mathrm{~m}^{2}$ per plot, which was spaced of $2 \mathrm{~m}$ among themselves. The coriander and Gallant soldier were planted between the tomato lines.

The plots in both systems had the soil ploughed and flower-bedded. Fertilization in the organic system was done with manure before the cultivation and in sidedressing applications. In the conventional system, fertilization consisted of N-P-K (Makishima \& Miranda, 1992). The irrigation was done by infiltration in the organic system and by sprinklers in the conventional one. All other agronomic practices, such as sprouting and conduction, followed the same technical recommendations for the crop (Makishima \& Miranda, 1992). In the conventional system, a blend of insecticides, fungicides and miticides was sprayed twice a week, after planting. The following fungicides chlorothalonil (3) and metalaxil+mancozebe (1) were applied at the rates recommended by the manufacturers; The following insecticides and miticides abamectin (4), espinosade (4) and cartap (3) to control SATP and thiomethoxam (4), acephate (4) and imidacloprid (2) to control whitefly were applied at the rates recommended by the manufacturers. Bordeaux mixture was applied twice during the experiment to control diseases and pests in the organic system. Weed control was carried out by mechanical weeding and with the herbicide glyphosate (directed spray) on post-planting in the conventional system, and with mechanical weeding in the organic system.

Delta traps containing traces of sexual SATP pheromones (iscalure Tuta) were distributed $1,0 \mathrm{~m}$ from the each experimental area not to interfere in the population samples within the areas. The traps were set up in the four corners of each area at $0.5 \mathrm{~m}$ above ground level. Traps were observed three times a week and the number of adult tomato pinworms captured was recorded.

The SATP population and its natural enemies were monitored in organic and conventional systems through weekly insects sampling. The number of pinworms eggs, larvae or adults were observed and counted in the field, as well as the other herbivores and natural enemies which were present from the ground to the apex, in five tomato plants/ plot picked at random. The collection period lasted 84 days, starting with the first issue of floral buds (24 days after the transplant) to the end of the harvest. The insects observed were classified on the feeding habit as herbivores, predators or parasitoids. The phenology of the plant as well as the weather and cultural data were recorded.

Data were statistically analyzed by multiple analysis of variance (two-way ANOVA) followed by the StudentNewman-Keuls test $(\mathrm{p}<0.05)$ or MannWhitney test $(\mathrm{p}<0.001)$ with the software Sigmastat V 3.2.

\section{RESULTS AND DISCUSSION}

The population densities of adult SATP present in the vicinities of the areas under organic and conventional management, in all samples with sexpheromone-baited delta traps, did not differ significantly (Fig. 1) (MannWhitney test: $\sigma=52,7$ organic and $\sigma=54,4$ conventional, value of $\mathrm{t}=$ $11,114, n=104, p=0,572)$. It means that the population of SATP adults was uniformly distributed between the experimental areas.

However, the populations of adult
SATP sampled within the plots showed different behavior in the two systems. The number of SATP adults was lower in the organic system, mainly in the treatment with the highest level of crop diversification (tomato-corianderGallant soldier), which was followed by tomato-coriander and tomato single, but there were no differences among them (Fig. 2-A) $\left(\mathrm{F}_{\text {week }}=17,153\right.$, g.1. $=$ $7, \mathrm{p}<0,001 ; \mathrm{F}_{\text {treatment }}=12,978$, g.1. $=5$, $\mathrm{p}<0,001 ; \mathrm{F}_{\text {week } x \text { treatment }}=2,369$, g.l. $=35$, $\mathrm{p}<0,001)$. However, in the conventional system, the adult population was higher, mainly at about 80 days after transplantation, when the adult numbers increased almost three-fold.

The organic cropping system showed lower numbers of SATP eggs when compared to the conventional system. In the conventional system, there were differences in the populations of eggs among weeks, among treatments within each week $(F=22,103$, g.l. $=7, p<0,001)$, among treatments, independently of the week $(\mathrm{F}=8,127, \mathrm{~g} .1 .=5, \mathrm{p}<0,001)$, and there was interaction between week $\mathrm{x}$ treatment $(\mathrm{F}=1,607$, g.1. $=35, \mathrm{p}=0,037)$. Although the collection period started with the first issue of floral buds (24 days after transplant), the variable observed began to differentiate from the fifty-two days after transplantation, when the coriander and Gallant soldier started their flowering season, and tomato plants bore small fruits. The highest numbers of SATP eggs occurred in the conventional cropping system from 80 to 94 days after transplantation, for the three crop diversification levels (Table 1). The significant differences found in this period among the levels of crop diversification indicate that the oviposition behavior of SATP females was affected by complexity of vegetation around the tomato plants. In the same period, the smallest number of eggs was found in the most diverse and organic systems (Table 1, treatments 2 and 3), although organic tomato monoculture system did not differ from the three crop diversification levels in the conventional systems.

The population of SATP caterpillars showed a different pattern from adults and eggs. The mean number of total caterpillars sampled throughout the 


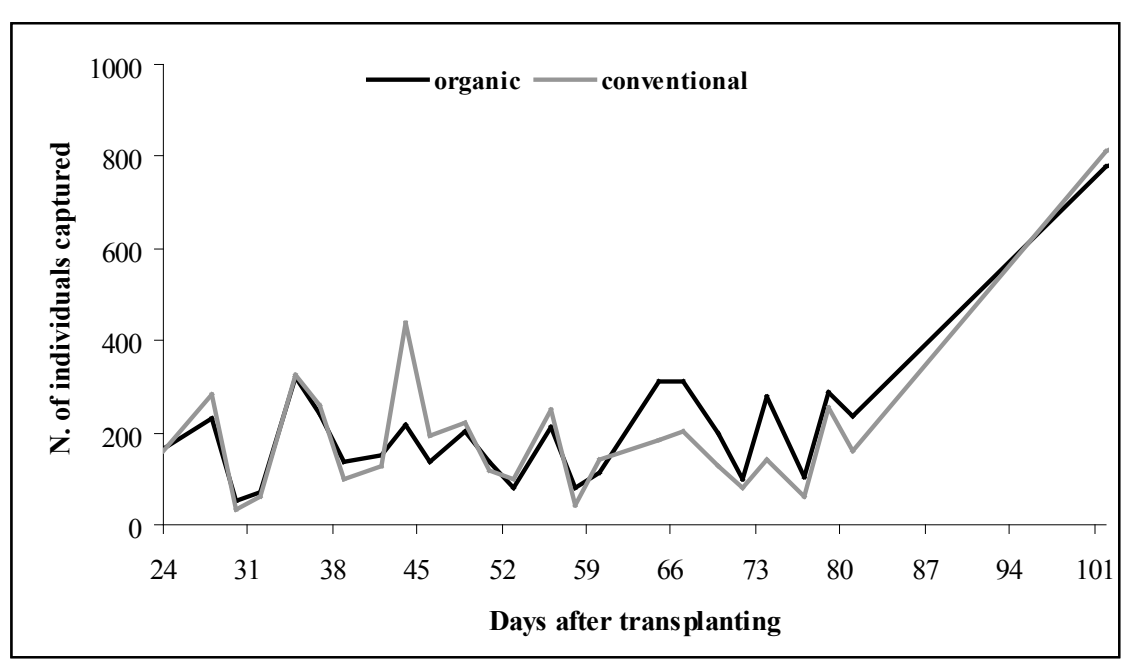

Figure 1. Adults of SATP captured by sexual pheromone traps which were placed in the edge of experimental areas under organic and conventional systems (adultos de traça-dotomateiro coletados em armadilhas de feromônio, as quais foram instaladas nas bordas das áreas experimentais sob sistemas orgânico e convencional). Brasília, Embrapa Hortaliças, 2004.

Means did not differ from each other by Mann-Whitney test $(\mathrm{p}<0.001)$ (médias não diferiram entre si pelo teste de Mann-Whitney $(\mathrm{p}<0.001))$.

Table 1. Mean number of SATP eggs per plot sampled in tomato crop with three levels of plant diversification in the organic system (1-tomato, 2-tomato-coriander, 3-tomatocoriander-Gallant soldier) and the conventional system (4-tomato, 5-tomato-coriander, 6-tomato-coriander-Gallant soldier) (número médio de ovos da traça-do-tomateiro por parcela amostrados na cultura do tomate com três níveis de diversificação de plantas no sistema orgânico (1- tomate, 2- tomate-coentro e 3- tomate-coentro-botão-de-ouro) e no sistema convencional (4- tomate, 5- tomate-coentro e 6- tomate-coentro-botão-de-ouro). Brasília, Embrapa Hortaliças, 2004.

\begin{tabular}{lrrrrrrrr}
\hline & \multicolumn{3}{c}{ Organic system } & & \multicolumn{3}{c}{ Conventional system } \\
\cline { 2 - 3 } \cline { 7 - 9 } Sample time & \multicolumn{1}{c}{$\mathbf{1}$} & $\mathbf{2}$ & $\mathbf{3}$ & & $\mathbf{4}$ & $\mathbf{5}$ & $\mathbf{6}$ \\
\hline 52 days & $4,6 \mathrm{~A}^{2} \mathrm{a}^{3}$ & $9,0 \mathrm{Aa}$ & $1,6 \mathrm{Aa}$ & & $9,6 \mathrm{Aa}$ & $7,6 \mathrm{Aab}$ & $8,3 \mathrm{Aac}$ \\
59 days & $7,0 \mathrm{Aa}$ & $6,3 \mathrm{Aa}$ & $2,6 \mathrm{Aa}$ & & $11,3 \mathrm{Aa}$ & $13,0 \mathrm{Aab}$ & $14,6 \mathrm{Aac}$ \\
66 days & $7,3 \mathrm{Aa}$ & $6,3 \mathrm{Aa}$ & $5,3 \mathrm{Aa}$ & & $4,6 \mathrm{Aa}$ & $7,0 \mathrm{Aab}$ & $4,0 \mathrm{Aac}$ \\
73 days & $6,0 \mathrm{Aa}$ & $1,3 \mathrm{Aa}$ & $1,0 \mathrm{Aa}$ & & $3,0 \mathrm{Aa}$ & $3,6 \mathrm{Aab}$ & $3,6 \mathrm{Aac}$ \\
80 days & $57,3 \mathrm{Ab}$ & $34,6 \mathrm{Aa}$ & $13,0 \mathrm{Aa}$ & & $59,0 \mathrm{Bb}$ & $82,0 \mathrm{Bbc}$ & $62,3 \mathrm{Bbc}$ \\
87 days & $2,3 \mathrm{Aa}$ & $2,0 \mathrm{Aa}$ & $0,3 \mathrm{Aa}$ & & $33,6 \mathrm{Bb}$ & $39,6 \mathrm{Bac}$ & $34,5 \mathrm{Bbc}$ \\
94 days & $21,0 \mathrm{Aa}$ & $11,6 \mathrm{Aa}$ & $3,3 \mathrm{Aa}$ & & $45,3 \mathrm{Bb}$ & $44,6 \mathrm{Bac}$ & $44,3 \mathrm{Bbd}$ \\
101 days & $21,6 \mathrm{Aa}$ & $13,0 \mathrm{Aa}$ & $13,3 \mathrm{Aa}$ & & $15,6 \mathrm{Aa}$ & $14,0 \mathrm{Aab}$ & $17,6 \mathrm{Aac}$ \\
\hline
\end{tabular}

${ }^{1}$ Days after transplantation (dias após o transplantio); ${ }^{2}$ Means followed by the same capital letters in the column did not differ from each other by Student-Newman-Keuls test $(p<0.05)$ (médias seguidas pelas mesmas letras maúsculas na coluna não diferem entre si pelo teste de Student-Newman-Keuls test $(\mathrm{p}<0.05))$; ${ }^{3}$ Means followed by the same small letters in the line did not differ from each other by Student-Newman-Keuls test $(\mathrm{p}<0.05)$ (médias seguidas pelas mesmas letras minúsculas na linha não diferem entre si pelo teste de StudentNewman-Keuls test $(\mathrm{p}<0.05))$.

tomato cycle did not differ statistically among treatments (Fig. 2-B) $\left(\mathrm{F}_{\text {week }}=\right.$ 27,290 , g.l. $=7, \mathrm{p}<0,001 ; \mathrm{F}_{\text {treatment }}=2,126$, g.l. $=5, \mathrm{p}=0,069 ; \mathrm{F}_{\text {week } \mathrm{x} \text { treatment }}=2,652$, g.l. $=35, \mathrm{p}<0,001)$. Considering that the mean number of eggs was smaller effective than the natural enemies, which were more abundant in the organic systems. Similar results were found by Andow (1990), who observed that the larval-pupae survival of herbivorous insects was greater in diverse habitats (with a diversity of spontaneous plants) than in simple ones.

In the conventional and organic system, other herbivorous species were found. However, higher densities of a few herbivorous species exhibited higher density in the conventional systems, such as the whitefly, besides SATP. In the organic system, the number of herbivorous species was higher than in the conventional system (Fig. 3-A) $\left(\mathrm{F}_{\text {week }}=4,380\right.$, g.l. $=7, \mathrm{p}<0,001 ; \mathrm{F}_{\text {treatment }}$ $=0,576$, g.l. $=5, \mathrm{p}=0,718 ; \mathrm{F}_{\text {week } \mathrm{x} \text { treatment }}$ $=1,674$, g.l. $=35, p=0,026$ ), but they were considered as secondary tomato pests, such as Helicoverpa zea Boddie and Spodoptera frugiperda (Smith) (Lepidoptera: Noctuidae). Medeiros \& França $^{1}$ also observed the presence of secondary pest in plantations without the interference of insecticides.

The most abundant natural enemies in the two cropping systems were predaceous arthropods, such as spiders (Aranae), ants (Formicidae) and ladybird beetles (Coccinellidae). The spiders were abundant with uniform distribution in the two systems. The ladybird beetles appeared only at the end of the cycle in the organic system, possibly attracted by the coriander inflorescences. Resende (2008) also found that higher number of ladybird beetles in the intercropping of collard with coriander than in the monoculture of collard, mainly in the flowering season of the coriander. The ants were more common in the conventional system. Other groups of predators were present, such as the bedbugs Geocoris sp. (Lygaeidae), Orius sp. (Anthocoridae), Nabis sp. (Nabidae), Staphylinidae, Syrphidae, Dolichopodidae, Dermaptera, the neuropteran Chrysoperla externa Hagen (Chrysopidae), Mantidae and Vespidae.

The greater abundance and diversity of predaceous species were found in the organic system. The number of predaceous in this system reached 


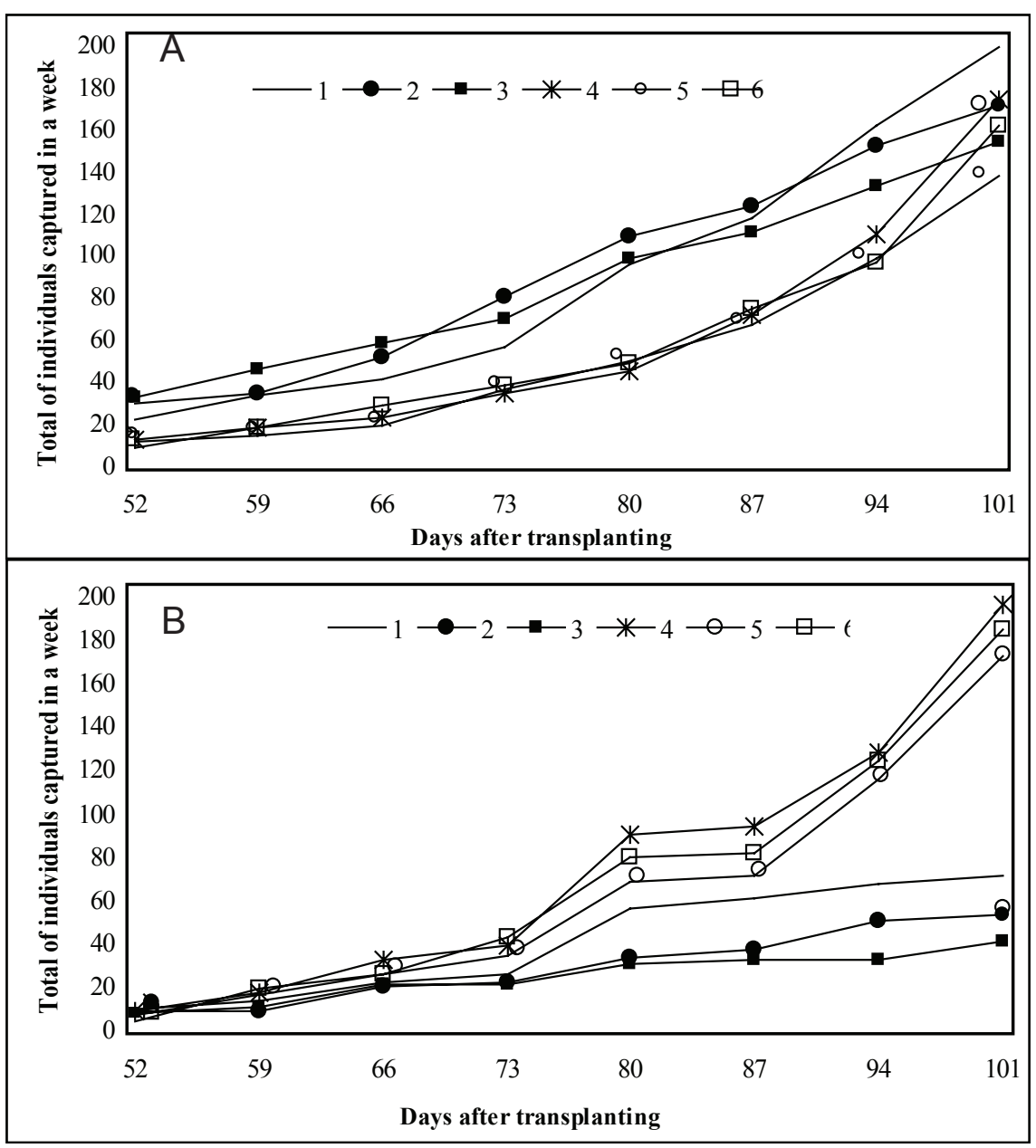

Figure 2. Acumulated number of adults (A) and caterpillar (B) of SATP sampled in tomato crop with three levels of plant diversification in the organic system (1-tomato, 2-tomatocoriander, 3-tomato-coriander-Gallant soldier) and the conventional system (4-tomato, 5-tomato-coriander, 6-tomato-coriander-Gallant soldier) (número acumulado de adultos (A) e lagartas (B) da traça-do-tomateiro amostrados na cultura do tomate com três níveis de diversificação de plantas no sistema orgânico (1- tomate, 2- tomate-coentro e 3- tomatecoentro-botão-de-ouro) e no sistema convencional (4- tomate, 5- tomate-coentro e 6-tomatecoentro-botão-de-ouro). Brasília, Embrapa Hortaliças, 2004.

Means were compared by Student-Newman-Keuls test $(\mathrm{p}<0.05)$ (médias foram comparadas pelo teste de Student-Newman-Keuls (p,0.05)). Brasília, DF, 2004.

the double of the number sampled in the conventional system at 80 days after transplantation (Fig. 3-B) $\left(\mathrm{F}_{\text {week }}\right.$ $=4,811$, g.1. $=7, \mathrm{p}<0,001 ; \mathrm{F}_{\text {treatment }}=$ 11,097 , g.l. $=5, \mathrm{p}<0,001 ; \mathrm{F}_{\text {week } x \text { treatment }}$ $=1,765$, g.l. $=35, \mathrm{p}<0,001)$, following the increase of population density of the tomato pinworm in both cropping systems, the number of predaceous was proportionately greater with the increase of crop diversification level. Apparently the plant diversity, including weed species, is important to increase

\footnotetext{
${ }^{1}$ Personnal communication
}

observed that Gallant soldier was very attractive to beneficial insects foraging in its flowers. However, Nascente (1998) studied the fauna of arthropods in tomato crops intercropped with four weed species, including Gallant soldier, and observed that the combination tomato/Gallant soldier attracted more herbivores, mainly Lygaeidae bugs associated with this weed. The most attracted combinations to predators and parasitoids were tomato/ Nightshade (Solanum americanum Mill.) (Solanacea), and tomato/brachiaria grass (Brachiaria plantaginea (Link.) (Poaceae).

Letourneau \& Goldstein (2001) observed that the damage to leaves and fruits of tomato caused by arthropods was similar among organic and conventional farms in California, USA, but the arthropod fauna was more diverse and the natural enemies were more abundant on organic farms. According to these authors, organic practices promote greater wealth of herbivores, so that the community is less dominated by a main pest. Additionally, the organic system methods promote the conservation of species of arthropods in all functional groups, which increases the abundance of natural enemies, compared to the conventional system.

The role of coriander in the system is still not clear, but at first glance, it may hinder the location of the plants by insects (Hilje, 2001). According to Andow (1990), non-host plants may interfere physically in the settlement of adults, and non-host plants reduced immigration and increased emigration of the herbivorous beetle Epilachna varivestis Mulsant (Coccinellidae), clearly affecting its behavior. The coriander also may cause repellence because of the chemical that they give off, as pointed out by Andow (1993), to mustard intercropped with beans. The chemicals of the mustard act as antifeedants for $E$. varivestis and contribute to the suppression of its populations in the intercropping of bean with mustard (Andow, 1993). However, the actions of the coriander on the system seem to be broader, once in the tenth week of the experiment, the coriander in bloom showed large amounts of 


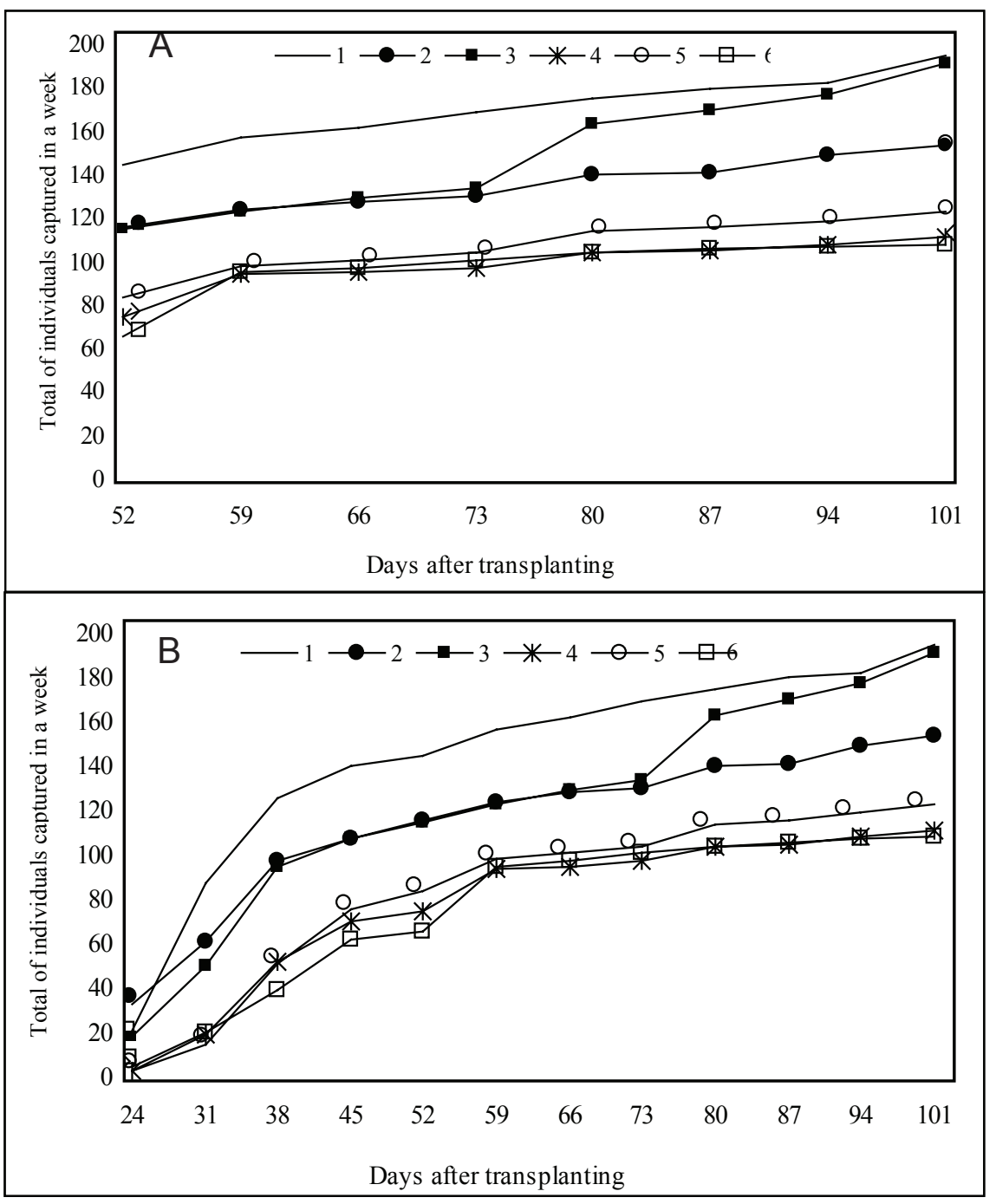

Figure 3. Acumulated number of herbivorous (A) and predaceous artropods (B) sampled in tomato crop with three levels of plant diversification in the organic system (1-tomato, 2-tomato-coriander, 3-tomato-coriander-Gallant soldier) and the conventional system (4-tomato, 5-tomato-coriander, 6-tomato-coriander-Gallant soldier) (número acumulado de herbívoros (A) e artrópodes predadores (B) amostrados na cultura do tomate com três níveis de diversificação de plantas no sistema orgânico (1- tomate, 2- tomate-coentro e 3- tomatecoentro-botão-de-ouro) e no sistema convencional (4- tomate solteiro, 5- tomate-coentro e 6- tomate-coentro-botão-de-ouro). Brasília, Embrapa Hortaliças, 2004.

Mean were compared by Student-Newman-Keuls test $(\mathrm{p}<0.05)$ (Médias foram comparadas pelo teste de Student-Newnam-Keuls $(\mathrm{p}, 0.05))$

aphids and in turn attracted a lot of ladybird beetles, such as Hippodamia convergens Guérin-Menéville, Cycloneda sanguinea L. and Eriopis connexa (Germar)(Coccinellidae), which were used as alternative preys. Resende (2008) also observed the infestation of coriander by aphis Aphis spiraecola Patch. (Aphididae) at the end of the flowering season, which was used as food for $C$. sanguinea. In the present study, there were a great number of these predators during the other following higher abundance). Andow \& Risch (1985) stated that, if the diversification resulted in greater abundance of food resources or greater spatial dispersion of food, then the predators may be more abundant and effective in a diversified agroecosystem.

Besides the SATP, common diseases of tomato such as tospovirus, geminivirus, bacterial wilt and powdery mildew affected the productivity of the organic system. Competition of coriander and Gallant soldier with tomato also had a direct effect on productivity. Probably, the organic system is capable of supporting a broad arthropod community, including a percentage of pests because there are several factors working simultaneously on the environment, i.e., it is the complementarity that makes the system viable.

Coriander and Gallant soldier associated with tomato affected the population dynamics of the arthropod community. Even though there is a significant difference between the population levels achieved in each cropping system, the influence of these companion plants can be checked by various indicators, such as lower densities of eggs and adults, greater wealth and abundance of general herbivores and generalist predators on both cropping systems, organic and conventional. Further studies should emphazise the following unknown aspects: 1) the associated plants can be used in a spatial arrangement that increases and conserves natural enemies and that, at the same time, does not present any negative influences on the crop, such as competition; 2) if management of these plants will be enough to ensure the protection of the tomato, allowing the production of organic tomatoes and 3) The environmental management to minimize the problems caused by the diseases of the tomato still remains to be studied.

\section{ACKNOWLEDGEMENTS}

We thank Hozanan Pires Chaves, José Gomes Teixeira for helping during the field work, to anonymous reviewers for suggestions on manuscript. This 
work is a part of the requirements from the Pos-Graduate Program of Ecology in the University of Brasilia for the achievement of Doctor in Sciences degree by Maria Alice de Medeiros.

\section{REFERENCES}

ALTIERI MA; SILVA EM; NICHOLLS CI. 2003. O papel da biodiversidade no manejo de pragas. Ribeirão Preto: Holos. 226 p.

ALTIERI MA; WHITCOMB WH. 1979. The potencial use of weeds in the manipulation of beneficial insects. HortScience 14: 12-18.

ANDOW DA. 1990. Populations dynamics of an insect herbivore in simple and diverse habitats. Ecology 7: 1006-1017.

ANDOW DA. 1991. Vegetational diversity and arthropod population response. Annual Review of Entomology 36: 561-586.

ANDOW DA. 1993. Mustard as an antifeedant for Epilachna varivestis adults (Coleoptera: Coccinelidae). Coleopterists Bulletin 47: 131-135.

ANDOW DA; RISCH SJ. 1985. Predation in diversified agroecosystems: relations between a coccinellid predator Coleomegilla maculata and its food. Journal of Applied Ecology 22: 357-372.

BERNDT LA; WRATTEN SD. 2005. Effects of alyssum flowers on the longevity, fecundity, and sex ratio of the leafroller parasitoid Dolichogenidea tasmanica. Biological Control 32: 65-69.

BOTELHO ACB; CURE JR; VILELA EF. 1994. Abundância e riqueza em espécies de insetos (herbívoros, predadores e parasitóides) em agroecossistema hortícola com manejo orgânico. Anais da Sociedade Entomológica do Brasil 23: 87-98.

BRUNHEROTTO R; VENDRAMIM JD. 2001. Bioatividade de extratos aquosos de Melia azedarach L. sobre o desenvolvimento de Tuta absoluta (Meyrick) (Lepidoptera: Gelechiidae) em tomateiro. Neotropical Entomology 30: 455-459.

CASTELO BRANCO M. 1992. Flutuação populacional da traça-do-tomateiro no Distrito Federal. Horticultura Brasileira 10: 33-34.

COLLEY MR; LUNA JM. 2000. Relative attractiveness of potential beneficial insectary plants to aphidophagous hoverflies (Diptera: Syrphidae). Environmental Entomology 29: 1054-1059.

EMDEN HF. 1965. The role of uncultivated land in the biology of crop pests and beneficial insects. Scientific Horticulture 17: 121-136.

FRANÇA FH. 1993. Por quanto tempo conseguiremos conviver com a traça-dotomateiro? Horticultura Brasileira 11: 176178 .
FRANÇA FH; VILLAS BÔAS GL; CASTELO BRANCO M.; MEDEIROS MA. 2000. Manejo integrado de pragas. In SILVA JBC; GIORDANO LB (orgs). Tomate para processamento industrial. Brasília: Embrapa Comunicação para Transferência de Tecnologia/Embrapa Hortaliças. p. 112-127.

GIUSTOLIN TA; VENDRAMIM JD; ALVES SB. 2001a. Efeito associado de genótipo de tomateiro resistente Bacillus thuringiensis var. kurstaki no desenvolvimento de Tuta absoluta (Meyrick) (Lep.: Gelechiidae). Neotropical Entomology 30: 461-466.

GIUSTOLIN TA; VENDRAMIM JD; ALVESS SA. 2001b. Patogenicidade de Beauveria bassiana (Bals.) Vuill. sobre Tuta absoluta (Meyrick) (Lepidoptera: Gelechiidae) criada em dois genótipos tomateiro. Neotropical Entomology 30: 417-421.

GRASSI TL. 2005. Desempenho de cultivares de tomate (Lycopersicon esculentum Mill.) sob sistemas orgânicos em cultivo protegido. Piracicaba: USP ESALQ. 87p. (Tese mestrado).

HAJI FNP; FREIRE ICI; ROA FG; SILVA CN; SOUZA JUNIOR MM; SILVA MIV. 1995. Manejo integrado de Scrobipalpuloides absoluta (Povolny) (Lepidoptera: Gelechiidae) no Submédio São Francisco. Anais da Sociedade Entomológica do Brasil 24: 587591.

HAJIFNP; OLIVEIRACAV;AMORIMNETOMS; BATISTA JGS. 1988. Flutuação populacional da traça-do-tomateiro no submédio São Francisco. Pesquisa Agropecuária Brasileira 23: 7-14.

HAJI FNP; PREZOTTI, L; CARNEIRO JS; ALENCAR JA. 2002. Trichogramma pretiosum para o controle de pragas no tomateiro industrial. In PARRA JPP; BOTELHO PS; CORRÊA-FERREIRA BS; BENTO JMS. (eds). Controle biológico no Brasil: parasitóides e predadores. São Paulo: Manole. p. 477-494.

HILJE L. 2001. Avances hacia el manejo sostenible del complejo mosca blanca-geminivirus en tomate, en Costa Rica. Manejo Integrado de Plagas 61: 69-80.

HOOKS CRR; JOHNSON MW. 2003. Impact of agricultural diversification on the insect community of cruciferous crops. Crop Protection 22: 223-238.

KUEPPER G; DODSON M. 2001. Companion planting: basic concepts \& resources. Fayetteville: Appropriate Technology Transfer for Rural Areas. 13p. Disponível em: http:// www.attra.org/attra-pub/complant.html. Acessado em 21 de novembro de 2008.

LANDIS DA; WRATTEN, S.D; GURR GM. 2000. Habitat management to conserve natural enemies of arthropod pests in agriculture. Annual Review of Entomology 45: 175-201.

LETOURNEAU DK; GOLDSTEIN B. 2001. Pest damage and arthropod community structure in organic vs. conventional tomato production in California. Journal of Applied Ecology 38: 557-570.

LOURENÇÃO AL; NAGAI H; ZULLO MAT. 1984. Fontes de resistência a Scropipalpula absoluta (Meyrick, 1917) em tomateiro. Bragantia 43: 569-577.

MAKISHIMA N; MIRANDA JEC. 1992. Cultivo do tomate (Lycopersicum esculentum Mill.). Brasília: EMBRAPA-CNPH. 22 p. (EMBRAPA-CNPH. Instruções Técnicas, 11).

NASCENTE AS. 1998. Interferência das plantas daninhas na cultura do tomate para processamento e a entomofauna associada. Brasília: UnB. 75p. (Tese mestrado).

NICHOLLS CI; ALTIERI MA. 2006. Bases agroecologicas para el manejo de la biodiversidad en agroecosistemas: efectos sobre plagas y enfermedades. Disponível em http://agroeco.org/brasil/material/efectos sobre plagas.htm. Acessado em 29 de junho de 2006.

PONTI L; ALTIERI MA; GUTIERREZ AP. 2007. Effects of crop diversification levels and fertilization regimes on abundance of Brevicoryne brassicae (L.) and its parasitization by Diaeretiella rapae (M'Intosh) in broccoli. Agricultural and Forest Entomology 9: 209-214.

RESENDE ALS. 2008. Comunidade de joaninhas (Coleoptera: Coccinellidae) e aspectos fitotécnicos da couve (Brassica oleraceae var. acephala) em consórcio com coentro (Coriandrum sativum), sob manejo orgânico. Seropédica: UFRRJ. 85p. (Tese mestrado).

RISCH SJ; WRUBEL R; ANDOW D. 1982. Foraging by a predaceous beetle, Coleomegilla maculata (Coleoptera: Coccinelidae), in a polyculture: effects of plant density and diversity. Environmental Entomology 11: 949-950.

ROOT RB. 1973. Organization of a plantarthropod association in simple and diverse habitats: the fauna of collards (Brassica oleracea). Ecological Monographs 43: 94125.

SMITH BC. 1960. A technique for rearing some coccinellid beetles on dry foods and influence of various pollens on the development Coleomegilla maculata lengi Tim. (Coleoptera: Coccinellidae). Canadian Journal of Zoology 38: 1047-1049.

SOUZA JC; REIS PR; SALGADO LO. 1992. Traça-do-tomateiro: histórico, reconhecimento, biologia, prejuízos e controle. Belo Horizonte: EPAMIG. 19 p. (Boletim Técnico, 38).

THOMAZINI APBW; VENDRAMIM, JD; BRUNHEROTTO R; LOPES MTR. 2001. Efeito de genótipos de tomateiro sobre a biologia e oviposição de Tuta absoluta (Meyrick) (Lep.:Gelechiidae). Neotropical Entomology 30: 283-288. 